実験的急性肝不全モデルの生存率に及注す免疫賦活剂の影響

$\begin{array}{lllll}\text { 溝口 } & \text { 靖紘 } & \text { 久保井広志 } & \text { 阪上 } & \text { 吉秀 関 守一 } \\ \text { 小林 } & \text { 絢三* } & \text { 山本 裙夫** } & \text { 森沢 } & \text { 成司*** }\end{array}$

要 旨：Propionibacterium acnes 加熱死菌をマウスに静注し，7 日後に少量のグラム陰性菌由 来の lipopolysaccharide(LPS)を静注すると, 、后とんどのマウスは広範な肝壊死を起こして死 亡する.しかし，このような実験的肝障害を誘導する際に，免疫賦活作用をもつOK 432を投与 すると、マウスの生存率は高くなり，肝の組織学的変化拈よび血清トランスフミナーゼも著明 に改善された.

以上の結果から本実験モデルの肝障害の誘導阻止に免度賦活剂が何らかの形で重要な役割を 果たしたと推測された。

臬引用語： 急性肝不全 免度賦活作用

OK432 lipopolysaccharide

Propionibacterium acnes

\section{緒言}

著者らは, グラム陽性嫌気性菌であるPropionibacterium acnes (P. acnes) 加熱死菌をマウスやラット に静注し, 7 日後に徵量のグラム陰性菌由来の内毒素, lipopolysaccharide (LPS) を静注すると, ほとんどの 動物は広範な肝壊死を起こして死亡することを観察し た ${ }^{1 \sim 3)}$. また急性肝不全発生の機序は, 䀒に集積した単 核細胞の中で粘着性細胞が P. acnes 括よびLPSに よって，二段階に活性化され，肝細胞障害因子産生 することを実験的に示しだ)。なお，この肝細胞障害因 子は蛋白性の物質であり，熱に比較的不安定な性質を 有する5).

一方, 劇症肝炎に和いては一般的には免疫の異常状 態にあり，免度過剩の結果起こると考えられている。 しかし，著者らが確立した急性肝不全モデルに沶いて 免度担当細胞を解析すると, 急性肝不全前駆状態では 網内系は充進し，その他の細胞活性は低下傾向にあり， 急性肝不全状態ではすべての免废担当細胞は著明に低 下していた ${ }^{6,7)}$. さらに, 一連の免度応答の様々な調節 因子にも異常が認められた に拉ける治療に関し，免疫賦活剂を導入する必要があ る可能性を示唆する。

*大阪市立大学医学部第 3 内科

**大阪社会医療センター

***大阪市立大学医学部第 1 生化学 〈受付日62年12月 25 日 >
そこで，著者らはこのような免没肝不全モデルを用 いて, 免疫賦活作用として OK 4329 12) 用い, OK 432 の生存率に括上ばす影響をinvivoの実験で検討し た.

1. 材料

\section{実験方法}

実験は BALB/c 系雄性マウス $(6 〜 8$ 週齢)をケ】 リー株式会社より購入して実験に供した。.P. acnesは 大阪市立大学医学部細菌学教室から贈与を受けた。 LPS は Salmonella minnesota 由来のむので Difco 社 から購入した、免废賦活隹としては OK 432を用い， OK 432は中外製薬研究所から供与された。

2. 急性肝不全の誘導法

マウス尾静脈から $1 \mathrm{mg} /$ マスの P. acnes 加熱死菌 を注入し， 7 日後に1 $\mu \mathrm{g} /$ マウスの LPSを静注した。

3. OK 432 の投与法

P. acnes 加熱死菌を220匹 (各群20匹) のマウス尾静 脈に投与し， 7 日後に各種濃度の OK 432を下記のよ らに 3 つの実験群にわけて腹腔内に投与した。

1) $0.1 \mathrm{KE} /$ ママスをたは $0.5 \mathrm{KE} /$ マゥスの濃度の OK 432 LPS の投与 1 時間前, 同時, 3 時間後に 3 回投与した。

2) $0.5 \mathrm{KE} /$ マウスの濃度の OK 432 LPS の投与 1 時間前, 同時, 3 時間後に 3 回, $0.5 \mathrm{KE} /$ マウスの濃 度の OK 432をLPS の投与 1 時間前，同時に 2 回，む るいは0.5KE/マウスの濃度の OK 432をLPSの投与 
1 時間前に 1 回投与した。

3) $0.5 \mathrm{KE} /$ マウスの濃度の OK 432をLPSの投与 1 時間前に 1 回， $0.5 \mathrm{KE} /$ マウスの濃度の OK 432 を LPS と同時に 1 回，あるいは0.5KE/マウスの濃度の OK 432を LPS の投与 1 時間後に 1 回投与した.

経時的にマウスの生存率を検討するととをにLPS 投与24時間後に生存したマウスの肝における組織学的 変化および血清トランスアミナーゼを調べた。

\section{実験結果}

1.急性肝不全誘尊マウスの生存率に乱よ卧 432 の影響

P. acnes 加熱死菌を静注し，7 日後に䵊量の LPS を 追加静注すると，すべてのマウスに急性阶不全が誘導 された，すなわち，LPS 静注 3 時間後より死亡例が発 現し，24時間後における生存率は0ー20\%であった。 これK対し，0.5KE/マウスの OK 432をLPSの投与 1 時間前，同時， 3 時間後に 3 回腹腔内に投与すると， 又0.1KE/マウスの OK 432 LPSの投与 1 時間前, 同時， 3 時間後に 3 回投与すると，Fig. 1 に示すよう にLPS 静注24時間後の生存率は著明に改善された(各 群 $\mathbf{n}=20, \mathrm{p}<0.01$ ). 次に0.5KE/マウスの OK 432 定 LPS の投与 1 時間前, 同時, 3 時間後に 3 回腹腔内に 投与すると，又0.5KE/マウスの OK 432をLPSの投 与 1 時間前，同時に 2 回腹腔内に投与すると，あるい は0.5KE/マウスの OK 432をLPSの投与 1 時間前に 1 回腹腔内に投与すると，生存率は著明に改善された （各群 $\mathrm{n}=20, \mathrm{p}<0.01$, Fig. 2).
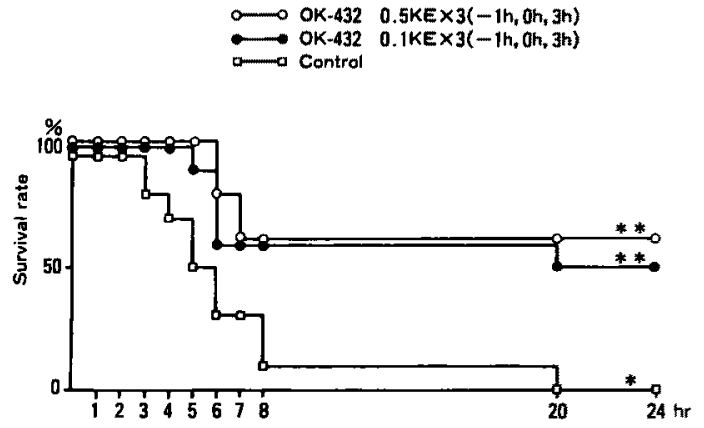

Fig. 1 Survival rate of mice administered with different doses of OK 432 . The mice were administered with $0.1 \mathrm{KE} /$ mouse of $\mathrm{OK} 432$ $-\mathrm{n}=20), 0.5 \mathrm{KE} / \mathrm{mouse}$ of $\mathrm{OK} 432(\mathrm{O}-\mathrm{O}$; $\mathrm{n}=20$ ) or saline solution (control; $\square-\square ; n=20$ ) one hour before, simultaneously with and 3 hours after LPS injection. ${ }^{*-* *}: p<0.01$

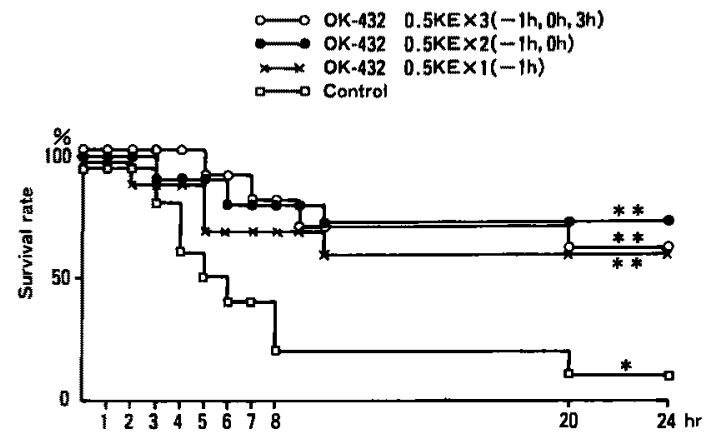

Fig. 2 Survival rate of mice administered with OK 432 for a different number of times. The mice were administered with $0.5 \mathrm{KE} /$ mouse of OK 432 three times one hour before, simultaneously with and 3 hours after LPS injection $(\mathrm{O}-\mathrm{O} ; \mathrm{n}=20$ ), two times one hour before and simultaneously with LPS injection ( $-n=20)$ or one time one hour before LPS injection $(x-x ; n=20)$ or with saline solution one time one hour before LPS injection (control ; $\square-\square ; n=20$ ). ${ }^{*-* *}: \mathrm{p}<$ 0.01

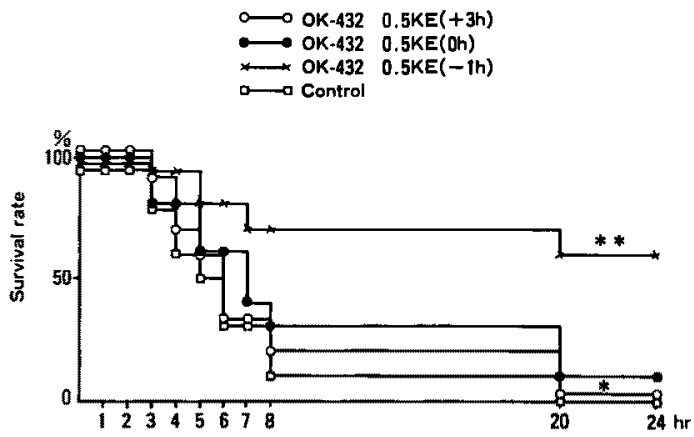

Fig. 3 Survival rate of mice administered with OK 432 at different times before and after LPS injection. The mice were administered with 0.5 $\mathrm{KE} /$ mouse of OK 432 one hour before LPS injection $(x-x ; n=20)$, simultaneously with LPS injection (- $; n=20$ ) or 3hours after LPS injection $(O-O ; n=20)$, or with saline solution one hour before LPS injection (control ; $\square-\square$; $\mathrm{n}=20$ ). ${ }^{*-* *}: \mathrm{p}<0.01$

さらに，0.5KE/マウスの OK 432を 1 回投与時期を 变㝋て腹腔内に投与すると, Fig. 3 に示すよ5にLPS の投与 1 時間前に投与した時のみ生存率が著明に改善 された（各群 $\mathrm{n}=20, \mathrm{p}<0.01$ ).

2. 急珄肝不全㛬導マウスにおける訮の組織学的変 


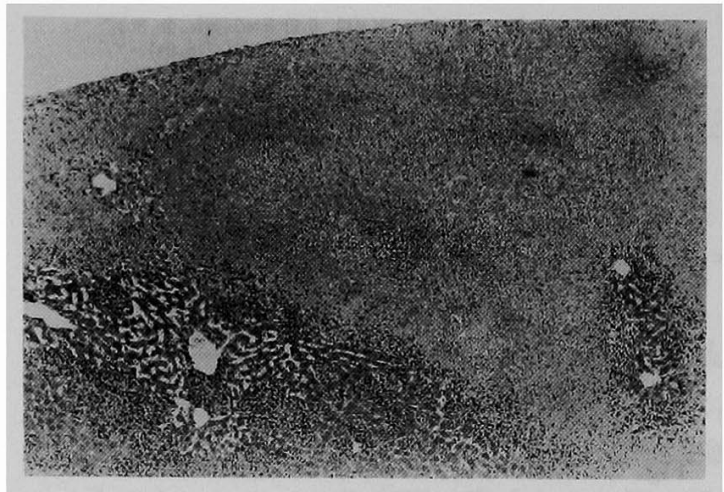

Fig. 4 Histological changes of liver from mice with acute hepatic failure (HE, $\times 40$ ).

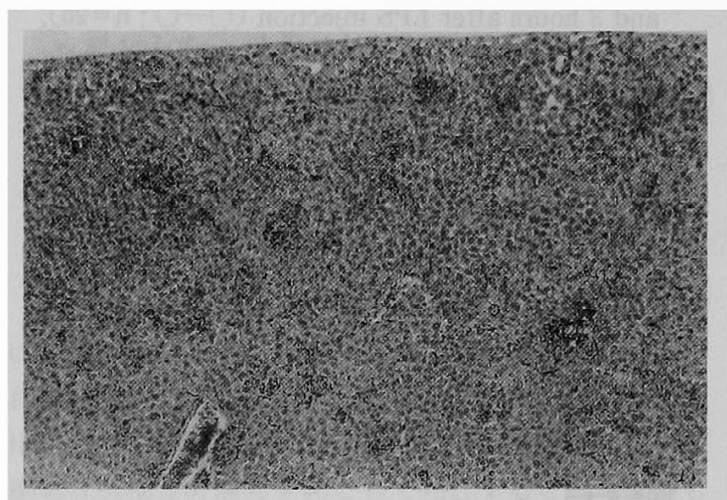

Fig. 5 Histological changes of liver from mice treated with OK $432(\mathrm{HE}, \times 40)$.

\section{化におよ汸す OK 432の影響}

急性肝不全を誘導したマウスのなかで LPS 静注 24 時間後まで生存したマウスについて, 肝の組織像を光 顕的に観察すると，すべてのマウスに広範な肝細胞の 变性怙よび壊死像が認められた（Fig. 4)。一方，0.5 $\mathrm{KE} /$ マゥゥスの OK 432を LPS 静注 1 時間前に投与し た群において，すべてにクリンン䩗および肝小葉内に マクロファーシシ，リンパ球，形質細胞などの単状の浸 潤は認められたが，肝細胞の変性または壊死像は汪と んど認められなかった (Fig. 5).

な执，Fig. 6 はその時の血清トランスアミナーゼを 測定したものである. OK 432の投与により GOT， GPT 著明に低下した $(\mathrm{n}=10)$ 。

\section{考察}

本邦の劇症肝资の大部分はウイルス性であるが，そ の劇症化の機序については種々の学説があり,なお, その詳細については不明である。 まして，免疫学的機
29巻 8 목 (1988)

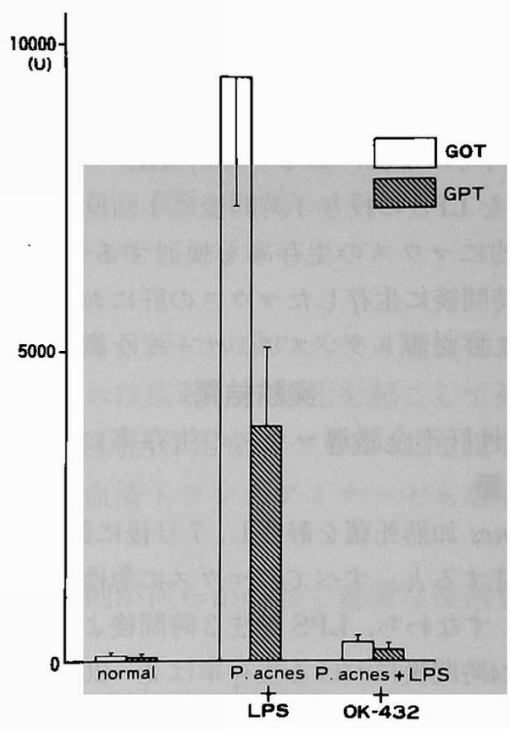

Fig. 6 Effects of OK 432 on serum transaminase of mice with acute hepatic failure $(n=10)$.

序についてはほとんど皆無である。しかし，その劇症 化の機序に免度が密接に関与していることは十分に想 像できる。

Dudley $ら^{131}$ は, B 型肝炎ウイルス感染で, 肝細胞の 障害の程度はウイルス感染した肝細胞の数と個体側の 細胞性免疫反応，すなわち $\mathrm{T}$ 細胞の機序によって決定 されるといら仮説を提唱し，劇症肝炎ではウイルスに 感染した肝細胞の数が多く，しかも $\mathrm{T}$ 細胞機能が過剩 な場合に発生すると考えている。 しかし，実際に臨床 症例で $\mathrm{T}$ 細胞の過㮃反応についての確諗はされてい ない.むしろ Singh ら ${ }^{14)}$ は T-cell rosette 数を検索し て $\mathrm{T}$ 細胞機能を検討し, $\mathrm{T}$ 細胞機能は低下傾向にある と述べている。

一方，B 型肝炎に打いては細胞性免疫に比較して体 液性免疫は急速にかつ過和反応が起こる. その結果, 抗体産生が過鄱になり免疫複合体が生じ，広範な肝細 胞壊死が発現すると考えられている ${ }^{15)}$. 実際に, IgG, IgA およびIgM む健常ヒトに比して上昇しているの で14)，体液性免疫が過剩反応を呈していることは間違 いない.

以上のように劇症肝炎症例では, 体液性免疫と細胞 性免疫とすに異常状態にあると考えられる。

さて，肝障害に endotoxinが重要な役割を果たして いる可能性について，今までに多くの研究者により報 告されており ${ }^{16)}$, 近年, 実験的 endotoxin 肝障害がヒ 
トの劇症肝炎に類似であるとして注目されている17)。 著者らす，単核細胞を肝に動員し，活性化すること により肝細胞障害が誘導されることを明らが し(-3)，この実験的急性肝不全に，特にマクロファーシ あるいは活性化 Kupffer 細胞が何らかの役割を果た している可能性を示した4). 著者らが確立した急性肝 不全モデルは, 病態におけるヒトの劇症肝炎とは異な るが, 肝細胞障害が重篤な点で類似しており，劇症肝 炎の治療方法の開発に有用であると考学る。

このような実験的に誘導した急性肝不全モデルを用 いて免疫担当細胞を検討すると, 肝内浸潤細胞のうち 粘着性細胞を除き他の免疫担当細胞は免疫低下状態に あった6).

この免疫担当細胞の機能低下の主な原因は，粘着性 細胞の機能变化，すなわち suppressor macrophage の 誘導のためである7. さらに T 細胞の増殖を左右する インターロイキン $1 ， 2$ の産生能の低下および反応性 の低下も判明している8”.

そこで著者らは免疫賦活剤が著者らが確立した免疫 学的急性肝不全モデルの生存率にどのような影響を括 よぼすかについて検討した。 その結果，兔疫䟼活作用 をるつOK 432は本モデルの生存率を著明に改善し た.

OK 432は各種の宿主機能の賦活作用を有すること が知られて拉り，好中球，マクロファージ，NK細胞， killer T 細胞等の活性化をるたらす ${ }^{9-11}$.さらに, イン ターロイキン 1,2 等のリンホカインの誘導作用もあ $z^{(2)}$. 今回 OK 432が急性肝不全モデルの誘導に抑制的 に作用した原因には、インターロイキン $1 ， 2$ 等の産生 を介して免疫系に対して調節的に作用した可能性之， OK 432投与による網内系の機能を高め endotoxin の spillover を阻止した可能性がある。これらの点に関し ては今後詳細な検討が必要と考える.

いずれにしても，免疫賦活剤の投与により実験的免 疫肝不全モデルの生存率が著明に改善されたことは， ヒトの劇症肝炎における治療に関し，免疫賦活上い5 概念を尊入する必要があるかるしれない，今後，ヒト により近い劇症肝炎モデルを用いての免疫担当細胞の 詳細な解析が必要と考学る。

$$
\text { 文献。 }
$$

1）筒井ひろ子, 溝口靖紘, 宮島度治, 他：急性肝不全 実铪モデルによる䀒細胞障害の検討．I. 䀒内粘着 性細胞に上る肝細胞障害の誘導について，日消誌 $82: 603-609,1985$
2）筒井ひろ子：実験的に誘導した急性肝不全マウス の免痃学的研究一実駼的急性肝不全の誘導とその 肝細胞障害機能について。肝䁍 $26: 1438-1444$, 1985

3) Tsutsui H, Mizoguchi $Y$, Yamamoto $S$, et al: Studies on experimentally-induced acute hepatic failure : Possible involvement of activated liver adherent cells. In: Cells of the Hepatic Sinusoid, Edited by Kirn A, et al. The Kupffer Cell Foundation, Amsterdam, 1986, 307-314

4) 简井ひろ子, 宮島序治, 溝口靖紘, 他：実験的に誘 導した急性肝不全マウスに認められる肝細胞障害 因子の性状化ついて，日消誌 $83 ： 1161-1167$, 1986

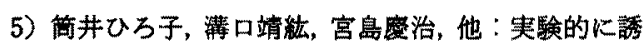
遵した急性肝不全に関する研究一肝細胞障害因子 々 tumor necrosis factor の異同について。 日消誌 $83: 1324-1329,1986$

6）筒井ひろ子, 满口靖紘, 加藤寞子, 他：急性肝不 全実験モデルによる肝細胞障害の研究. II 脾細胞, 末梢血単核細胞および腹腔出細胞の機能变化. 日消誌 $82: 1520-1526 ， 1985$

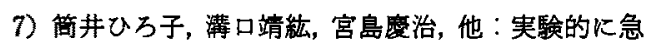
性肝不全を誘導したマウス脾細胞の mitogen 刺 教に対する応答低下及びその機序について，日消 誌 $82 ： 2752-2760,1985$

8）筒井ひ万子, 溝口靖䌅, 宮島度治, 他：実験的に急 性肝不全を誘導したマウスの脾細胞に打けるイン ターリニーキン1および2の産生について，日消 誌 $84: 1090-1096,1987$

9) Satio $M$, Ebina $T$, Ishida $N$, et al: Induction of interferon in mouse spleen cells by OK432, a preparation of streptococcus pygenes. Cell Immunol 68 : 187-192, 1982

10) Hojo H, Hashimoto $Y$ : Cytotoxic cells induced in tumor-bearing rats by a streptococcus preparation (OK432). Gann 72 : 692-699, 1981

11) Uchida $A$, Micksche $M:$ In vitro augmentation of natural killing activity by OK432. Int J Immuno Pharmac $3: 366-375,1981$

12）市村 鈴木清吉, 斉藤元男, 他：OK432による マウス interleukin 1 および interleukin 2 の産生 増強作用. 医学のあ妕 $127 ： 296$-298，1983.

13) Dudley FJ, Fox RA, Sherlock S: Cellular immunity and hepatitis-associated, Australia antigen liver disease. Lancet 1: 723-726, 1972 
14) Singh NK, Goyal AK, Srivastava PK, et al : Immunological status in acute viral hepatitis and fluminant hepatic failure. J Indian Med Assoc $82: 281-283,1984$

15) Almeida JD, Waterson AP : Immune complexes in hepatitis. Lancet $2: 983-986,1969$
16) Nolan JP: The role of endotoxin in liver injury. Gastroenterology $69: 1346-1356,1975$

17) Nolan JP, Leibowitz AI: Endotoxin and the liver. III Modification of acute carbon tetracholoride injury by polymyxin B-An antiendotoxin. Gastroenterology $75: 445-449,1978$

\title{
Effects of an immunostimulant, OK432, in an experimentally-induced acute hepatic failure model
}

\author{
Yasuhiro Mizoguchi, Hiroshi KuboI, Yoshihide SaKagami, Shuichi SekI, \\ Kenzo KobaYashi*, Sukeo Yamamoto** and Seiji MoRISAWA***
}

Acute hepatic failure was induced by an i.v. injection of heat-killed Propionibacterium acnes into $\mathrm{BALB} / \mathrm{c}$ mice followed by an i.v. injection of a minute amount of lipopolysaccharide (LPS). Most of the mice died of massive hepatic necrosis within 24 hours of i.v. LPS injection. However, an i.p. administration of an immunostimulant, OK432, one hour before LPS injection prevented the mice from death due to hepatic failure and diminished the development of histological changes, especially hepatic necrosis. These results suggest that the generation of OK432 may be involved in the development of acute hepatic failure in the present model.

* The Third Department of Internal Medicine, Osaka City University Medical School (Osaka)

** The Osaka Socio-Medical Center Hospital (Osaka)

*** The First Department of Biochemistry, Osaka City University Medical School (Osaka) 